\title{
PENGARUH BUDAYA ORGANISASI, LOCUS OF CONTROL, STRES KERJA TERHADAP KINERJA APARAT PEMERINTAH DAERAH DAN KEPUASAN KERJA SEBAGAI VARIABEL INTERVENING (Studi Empiris Pada Pemerintah Kabupaten Bengkalis)
}

\author{
Endang Sri Wahyuni ${ }^{1 *}$, Taufeni Taufik ${ }^{2}$ dan Vince Ratnawati ${ }^{2}$ \\ ${ }^{1}$ Program Studi Magister Akuntansi Pasca Sarjana Universitas Riau \\ ${ }^{2}$ Fakultas Ekonomi Universitas Riau \\ Email :endang.sri@polbeng.ac.id
}

\begin{abstract}
Abstrak: Penelitian ini bertujuan untuk mengetahui pengaruh budaya organisasi, locus of control, dan stres kerja terhadap kinerja aparat pemerintah daerah dan untuk mengetahui peran kepuasan kerja dalam memediasi pengaruh budaya organisasi, locus of control, stres kerja terhadap kinerja aparat pemerintah daerah. Penelitian ini dilakukan di Pemerintah Kabupaten Bengkalis dengan menggunakan quesioner untuk 183 responden, teknik analisis yang dipergunakan adalah teknik analisis jalur (parth analysis) dengan menggunakan program SPSS versi 17.0. Hasil penelitian menunjukkan bahwa variabel budaya organisasi berpengaruh terhadap kinerja aparat pemerintah daerah, locus of control berpengaruh terhadap kinerja aparat pemerintah daerah dan stres kerja berpengaruh terhadap kinerja pemerintah daerah. Variabel kepuasan kerja memediasi pengaruh budaya organisasi terhadap kinerja aparat pemerintah daerah, kepuasan kerja memediasi pengaruh locus of control terhadap kinerja aparat pemerintah daerah, dan kepuasan kerja memediasi pengaruh stres kerja terhadap kinerja aparat pemerintah daerah.
\end{abstract}

Kata Kunci : Kinerja Aparat Pemerintah Daerah, Budaya Organisasi, Locus of Control, Stres Kerja, Kepuasan Kerja.

Abstract: This purpose of this study is to examine the effect of organizational culture, locus of control, and job stress on the performance apparatus of district governments, this study also examine the mediating role of job satisfaction effect on organizational culture, locus of control, work stress on the performance of district governments. The population in this study are all of SKPD Bengkalis District Government and purposive sampling is used as sampling method. This study uses questioner for 183 respondents. The analysis technique used is the technique of path analysis using SPSS version 17.0. The results showed prove that organizational culture affect on the performance apparatus of district governments, locus of control affect on the performance apparatus of district governments, and job stress effect on the performance apparatus of district governments. Job satisfaction variable as mediating the effect of organizational culture on the performance apparatus of district governments, Job satisfaction variable as mediating the effect of locus of control on the performance apparatus of district governments, Job satisfaction variable as mediating the effect of job stress on the performance apparatus of district governments.

Keywords: Performance Apparatus of District Governments, Organizational Culture, Locus Of Control, Job Stress, and Job Satisfaction. 


\section{PENDAHULUAN}

Kinerja pemerintah merupakan salah satu isu yang terdapat dalam ranah sektor publik di Indonesia. Kinerja menjadi gambaran mengenai tingkat pencapaian pelaksanaan suatu kegiatan dalam mewujudkan sasaran, tujuan, visi dan misi organisasi yang tertuang dalam strategi perencanaan suatu organisasi. Sistem akuntabilitas pemerintah yang diatur dalam Peraturan Presiden No. 29 Tahun 2014 dan Laporan Akuntabilitas Kinerja Pemerintah (LAKIP) yang diatur pada Inpres No. 7 Tahun 1999 adalah pedoman penting bagi pemerintah untuk dapat mewujudkan pemerintahan yang lebih berdaya guna. Menurut Spekle dan Verbeeten (2008), bahwa Sistem pengukuran kinerja merupakan kunci utama dalam mewujudkan manajemen sektor publik yang efektif, efisien dan akuntabel. Namun, pada kenyataannya praktik kinerja di Indonesia masih belum berperan dalam meningkatkan akuntabilitas kinerja instansi pemerintah daerah. Nurkhamid (2008) menemukan bahwa kemampuan pengukuran kinerja untuk mewujudkan transparansi dan akuntabilitas kinerja pemerintah masih dipertanyakan, hal tersebut disinyalir karena implementasi dan pengembangan pengukuran kinerja masih sebatas paksaan atas regulasi yang ada (Silaloho dan Halim, 2005)

Laporan hasil Evaluasi Akuntabilitas Kinerja Instansi Pemerintah menunjukkan kriteria penilaian untuk Kementrian/Lembaga (K/L) dan pemerintah provinsi di Indonesia, terlihat jumlah yang memperoleh prediket A (sangat baik) sebanyak 7 dari kementrian/lembaga dan hanya 2 provinsi selanjutnya yang mendapat prediket B (baik) berjumlah $43 \mathrm{~K} / \mathrm{L}$ dan 8 provinsi. Kemudian yang mendapat prediket CC (Cukup baik) sebanyak $32 \mathrm{~K} / \mathrm{L}$ dan 19 Provinsi, sedangkan yang mendapat prediket $\mathrm{C}$ (agak kurang baik) $1 \mathrm{~K} / \mathrm{L}$ dan 4 provinsi. Dari prediket diatas tidak ada pemerintah daerah (Provinsi dan Kabupaten/Kota) di Indonesia yang mendapat prediket A (memuaskan). Sehingga hal ini berarti kinerja instansi pemerintah di Indonesia masih rendah dan memprihatikan. Begitu juga penelitian yang dilakukan oleh Taufik (2013) yang melakukan penelitian tentang peran monitoring dan evaluasi terhadap akuntantabilitas Instansi Pemerintah Daerah bahwa rendahnya pencapaian akuntabilitas kinerja pemerintah baik pusat mapun daerah, disebabkan karena masih rendahnya komitmen kepala daerah dan seluruh staf instansi untuk melakukan pengelolaan pelaksanaan misi agar akuntabel, ini dibuktikan dengan begitu banyaknya kepala daerah yang terjerat dalam kasus hukum sehingga tidak tercapainya kinerja yang maksimal.

Lebih lanjut berdasarkan Peraturan Pemerintah Nomor 8 tahun 2006 "Setiap instansi pemerintah baik dari pusat maupun di daerah wajib menyusun laporan keuangan yang dilengkapi dengan laporan kinerja”. Dari hasil evaluasi akuntabilitas kinerja instansi pemerintah daerah (AKIP) Kabupaten/Kota tahun 2014, Kabupaten Bengkalis yang merupakan salah satu Kabupaten yang memperoleh predikat C (agak kurang baik) yang artinya Kabupaten Bengkalis memiliki kinerja yang kurang diandalkan, dan perlu mendapat perbaikan yang mendasar. Sementara itu untuk nilai rata-rata tahun 2014 sebanyak 36,60\%. Jika dibandingkan dengan nilai rata-rata tahun 2013 mencapai 43,78\%, sehingga terjadi penurunan kinerja sebesar 7,18\%.

Dalam mempercepat penyerapan anggaran di SKPD yang ada di lingkungan pemerintah Kabupaten Bengkalis, semua SKPD harus fokus pada realisasi anggaran dan mempercepat pelaksanaan program dan kegiatan sehingga tidak adanya SILPA di akhir tahun yang terlalu besar. Namun Kementrian Keuangan tahun 2015 merilis bahwa Kabupaten Bengkalis termasuk salah satu kabupaten yang memiliki dana menganggur 
(dana idle) di perbankan ketiga terbesar setelah Kutai Kartanegara dan Malang. Jika daerah-daerah di Kabupaten tersebut tidak memperbaiki penyerapan anggarannya hingga akhir tahun 2015 maka akan mendapatkan saksi tahun berikutnya berupa: 1) Dengan mengonversi dana transfer ke daerah dalam bentuk non tunai, yaitu Surat Utang Negara (SUN); 2) Dengan mengurangi dan menghentikan panyaluran Dana Alokasi Khusus (DAK) tahun berikutnya. Hal tersebut menjadi tolak ukur bagi SKPD khususnya untuk lebih mempercepat pelaksanaan program maupun kegiatan yang ada di masing-masing SKPD agar kinerja pemerintah daerah Kabupaten Bengkalis secara keseluruhan dapat lebih optimal.

Secara umum kinerja dipengaruhi oleh dua faktor, yaitu faktor internal dan eksternal (Ismail, 2006 dalam Abdulloh, 2006). Faktor internal merupakan faktor yang berasal dari dalam diri pegawai, yang meliputi kepuasan kerja dan locus of control. Sedangkan faktor eksternal merupakan faktor yang berasal dari luar diri pegawai yang meliputi kepemimpinan, keamanan, keselamatan kerja serta budaya organisasi.

Hofstede (1990) menyatakan bahwa budaya organisasi merupakan bagian dari kehidupan organisasi yang mempengaruhi perilaku, sikap, dan efektivitas seluruh pegawai. Indikasi penerapan budaya organisasi masih dirasakan kurang kuat, yang ditunjukkan dengan penurunan semangat kerja dan disiplin kerja pegawainya.

Selain berpengaruh terhadap kinerja, budaya organisasi juga memiliki kaitan yang erat dengan kepuasan kerja. Kepuasan kerja didefinisikan sebagai suatu keadaan yang emosional yang menyenangkan atau tidak menyenangkan dimana para karyawan memandang pekerjaannya (Widodo, 2006 dalam Abdulloh, 2006). Apabila persepsi terhadap budaya dalam suatu organisasi baik maka pegawai akan merasa puas terhadap pekerjaannya. Sebaliknya apabila persepsi pegawai terhadap budaya tidak baik, maka pegawai cenderung tidak puas terhadap pekerjaannya (Robbins dan Judge, 2008). Pegawai yang merasa puas terhadap pekerjaannya dan menganggap pekerjaannya sebagai sesuatu yang menyenangkan akan cenderung memiliki kinerja yang baik.

Selain budaya organisasi salah satu atribut kepribadian untuk menjelaskan perilaku manusia dalam organisasi adalah locus of control. Menurut Spector (1982), bahwa locus of control berhubungan dengan motivasi, usaha, kinerja, kepuasan kerja, persepsi terhadap pekerjaan, dan gaya kepemimpinan. Lebih jauh, dikemukakan bahwa locus of control dapat memoderasi hubungan antara insentif dengan motivasi, dan antara kepuasan kerja dengan turnover.

Disamping itu, perubahan-perubahan yang terjadi dalam instansi pemerintahan, tingkat kebutuhan dan berbagai persoalan lain yang menuntut adanya kemampuan dari sumber daya manusia untuk dapat menyesuaikan diri baik secara fisik maupun psikis. Karena apabila penyesuaian tersebut gagal atau salah maka akan mengakibatkan stres ditempat kerja sehingga dapat disimpulkan bahwa stres kerja timbul karena tuntutan lingkungan dan tanggapan setiap individu dalam menghadapinya. Stres kerja adalah sesuatu mengenai lingkungan kerja atau sifat pekerjaan itu sendiri yang menyebabkan stres yang dirasakan oleh individu (Bokti dan Mansor, 2009). Menurut Bimantoro (2012) secara bersama-sama ada pengaruh yang positif dan signifikan antara faktor lingkungan, faktor organisasi, dan faktor individu terhadap kinerja karyawan. Hal ini berarti bahwa semakin tinggi faktor lingkungan organisasi, dan faktor individu semakin tinggi kinerja karyawan.

Hubungan secara teoritis tersebut didukung oleh beberapa penelitian empiris yang juga menemukan bahwa budaya organisasi, locus of control, kepuasan kerja berpengaruh 
positif terhadap kinerja dan stres kerja berpengaruh negatif terhadap kinerja (misalnya Abdulloh (2006); Mohamad Noer (2007); Frucot dan Shearon (1997); Menez (2008); Chen dan Silverthorne (2008); Rozikin (2006)). Namun terdapat pula beberapa penelitian empiris yang menemukan bahwa budaya organisasi, locus of control, dan kepuasan kerja tidak berpengaruh terhadap kinerja (misalnya Kurniawan dan Andri (2012); Artiningsih dan Rasyid (2013)).

Untuk melihat lebih lanjut pengaruh budaya organisasi, locus of control, stres kerja dan kepuasan kerja terhadap kinerja pemerintah daerah, maka yang menjadi pertanyaan dalam penelitian ini adalah "Apakah budaya organisasi, locus of control, stres kerja berpengaruh terhadap kinerja aparat pemerintah daerah? Dan Apakah kepuasan kerja memediasi pengaruh budaya organisasi, locus of control dan kinerja aparat pemerintah daerah di Kabupaten Bengkalis?”.

\section{KAJIAN TEORI}

Kinerja Aparat Pemerintah Daerah. Menurut Indra, (2006) Kinerja adalah gambaran pencapaian pelaksanaan suatu kegiatan/ program/ kebijaksanaan dalam mewujudkan sasaran, tujuan, misi dan visi organisasi. Foster dan Seeker (2001) menyatakan bahwa, kinerja adalah hasil yang dicapai seseorang menurut ukuran yang berlaku untuk pekerjaan yang bersangkutan. Kinerja individu adalah hasil kerja pegawai baik dari segi kualitas maupun kuantitas berdasarkan standar kerja yang telah ditentukan, sedangkan kinerja organisasi adalah gabungan dari kinerja individu dan kinerja kelompok.

Aparatur Negara merupakan pelaksana roda birokrasi. Menurut Sedarmayanti (2009) bukunya yang berjudul Manajemen Sumber Daya Manusia Reformasi Birokrasi dan Manajemen Pegawai Negeri Sipil, birokrat adalah: (1) Birokrat adalah pegawai yang bertindak secara birokratis; (2) Birokrat adalah: (a) Sistem pemerintahan yang dijalankan oleh pegawai pemerintah karena telah berpegang pada hierarki dan jenjang jabatan;(b) Cara bekerja atau susunan pekerjaan yang serba lamban serta menurut tata aturan (adat dan sebagainya) yang banyak liku-likunya.

Terdapat 9 indikator yang digunakan untuk mengukur kinerja aparat pemerintah daerah, diantaranya: planning (perencanaan), investigating (investtigasi/ pemeriksaan), coordinating (koordinasi), evaluating (evaluasi), supervising (pengawasan), staffing (pemilihan staf), negotiating (negosiasi), representing (perwakilan), rate your overall performance (tingkat kinerja secara keseluruhan) (Mahoney, 1963).

Budaya Organisasi. Budaya organisasi adalah kerangka kerja yang menjadi pedoman tingkah laku sehari-hari dan membuat keputusan untuk karyawan dan mengarahkan tindakan untuk mencapai tujuan organisasi (Rivai \& Mulyadi, 2012). Menurut Kreitner dan Kinicki (2003) budaya organsasi adalah suatu wujud anggapan yang dimiliki diterima secara implisit oleh kelompok dan menentukan bagaimana kelompok tersebut merasakan, memikirkan dan bereaksi terhadap lingkungannya yang beraneka ragam.

Menurut Hofstede (1990) budaya bukan lah perilaku yang jelas atau benda yang dapat terlihat dan diamati oleh seseorang. Budaya juga bukan falsafah atau sistem nilai yang diucapkan atau ditulis dalam anggaran dasar organisasi tetapi budaya adalah asumsi yang terletak dibelakang nilai dan menentukan pola perilaku individu terhadap nilai-nilai organisasi, suasana organisasi dan kepemimpinan. Untuk mengukur variabel budaya organisasi terdapat 7 indikator yang berpengaruh terhadap budaya organisasi, diantaranya: 
inovasi dan pengambilan resiko, perhatian terhadap detail, orientasi ke keluaran, orientasi ke orang, orientasi team, keagresifan, stabilitas (Robbins, 2007).

Locus Of Control (LOC). Menurut Rotter (1986) menyatakan bahwa locus of control sebagai tindakan dimana seseorang menerima tanggung jawab personal terhadap apa yang terjadi pada diri mereka. Internal control mengacu pada persepsi terhadap kejadian baik positif maupun negatif sebagai konsekuensi dari tindakan/perbuatan diri sendiri dan berada dibawah pengendalian dirinya. Sedangkan eksternal control mengacu pada keyakinan bahwa suatu kejadian tidak memiliki hubungan langsung dengan tindakan yang telah dilakukan oleh diri sendiri dan berada diluar kontrol dirinya (Lefcourt, 1986 dalam Menez, 2008).

Menurut Crider (1983) perbedaan karakteristik antara locus of control internal dan eksternal adalah (a) Suka bekerja keras (b) Memiliki insiatif yang tinggi (c) Selalu berusaha untuk menemukan pemecahan masalah (d) Selalu mencoba untuk berfikir seefektif mungkin (d) Selalu mempunyai persepsi bahwa usaha harus dilakukan jika ingin berhasil. Sedangkan yang eksternal adalah (a) Kurang memiliki inisiatif (b) Mudah menyerah, kurang suka berusaha karena mereka percaya bahwa faktor luarlah yang mengontrol (c) Kurang mencari informasi (d) Mempunyai harapan bahwa ada sedikit korelasi antara usaha dan kesuksesan (e) Lebih mudah dipengaruhi dan tergantung pada petunjuk orang lain.

Indikator untuk mengukur variabel locus of control adalah: kegagalan yang dialami individu karena ketidak mujuran, perencanaan jauh ke depan pekerjaan yang sia-sia, kejadian yang dialami dalam hidup ditentukan oleh orang yang berkuasa, kesuksesan individu karena faktor nasib, segala yang dicapai individu hasil dari usaha sendiri, menjadi pimpinan karena kemampuan sendiri, keberhasilan individu karena kerja keras, segala yang diperoleh individu bukan karena keberuntungan, kemampuan individu dalam menentukan kejadian dalam hidup, kehidupan individu ditentukan oleh tindakannya, kegagalan yang dialami individu akibat perbuatan sendiri. (Rotter, 1996; dalam Chi Hsinkuang at al. 2010).

Stres Kerja. Menurut Kreitner dan Kinicki (2005), Stres adalah suatu respons yang adaptif, dihubungkan oleh karakteristik dan/atau proses psikologis individu, yang merupakan suatu konsekuensi dari setiap tindakan eksternal, situasi atau peristiwa yang menempatkan tuntutan psikologis dan/atau fisik khusus pada seseorang. Kondisi lingkungan yang khas sebagai sumber yang potensial terjadinya stress, kondisi semacam itu disebut penekan. Stres sangat mungkin dialami atau tidak oleh seseorang tergantung pada karakteristik orang yang bersangkutan. Yaitu adanya orang yang terlalu memikirkan sesuatu sehingga gampang untuk stres. Tetapi ada juga orang yang tidak terlalu memikirkan sesuatu sehingga tidak gampang stres.

Menurut Charles D, Spielberger (dalam Handoyo, 2001:63) menyebutkan bahwa stres adalah tuntutan-tuntutan eksternal yang mengenai seseorang, misalnya obyek-obyek dalam lingkungan atau suatu stimulus yang secara obyektif adalah berbahaya. Stres juga biasa diartikan sebagai tekanan, ketegangan atau gangguan yang tidak menyenangkan yang berasal dari luar diri seseorang. Indikator untuk mengukur variabel Stres Kerja adalah: Konflik, Ambiguitas, Beban Kerja dan Sumber Daya yang tidak memadai (Price, 2001). 
Kepuasan Kerja. Menurut Robbins (2007), kepuasan kerja (job satisfaction) merupakan sikap umum atau reaksi efektif seorang individu terhadap pekerjaannya yang berasal dari perbandingan hasil aktual pemegang jabatan dengan apa yang diinginkan. Smith et al (1996) mengatakan bahwa kepuasan kerja adalah perasaan pekerja terhadap pekerjaannya, hal ini merupakan sikap umum terhadap pekerjaan yang didasarkan pada penilaian aspek yang berada dalam pekerjaan. Sikap seseorang terhadap pekerjaan menggambarkan pengalaman yang menyenangkan dan tidak menyenangkan, juga berhubungan dengan harapan dimasa mendatang.

Kepuasan kerja mencerminkan kegembiraan atas sikap emosi positif yang berasalah dari pengalaman kerja seseorang (Judge dan Locke, 1993 dalam Retno, 2005). Kegembiraan yang dirasakan seseorang akan memberikan dampak positif baginya. Apabila seseorang puas akan pekerjaan yang dijalaninya, maka rasa senang pun akan datang, terlepas dari rasa tertekan, sehingga akan menimbulkan rasa aman dan nyaman untuk selalu bekerja dilingkungan kerjanya.

Terdapat 4 indikator kepuasan kerja (Job satisfaction) menggunakan intrumen Minnesota Satisfaction Questionnaire (MSQ) dengan skala likert 5 poin dengan 20 item. Satisfaction dikembangkan oleh Weiss et.al (1967 dalam Brownell, 1982). Dimensi pengukuran MSQ diantaranya; ability utilization (kemampuan pemanfaatan), achievement (prestasi), activity (aktivitas), advancement (kemajuan), authority (otoritas), company policies and practices (kebijakan perusahaan dan praktek), compensation (kompensasi), co-workers (rekan kerja), creativity (kreativitas), independence (kemerdekaan), moral values (nilai moral), recognition (pengakuan), responsibility (tanggungjawab), security (keamanan), social service (layanan sosial), social status (status sosial), supervisionhuman relations (pengawasan hubungan rekan kerja), supervision-technical (pengawasan teknis), variety (keanekaragaman), working conditions (kondisi kerja), general satisfaction (kepuasan secara menyeluruh)

Menurut Rivai (2012, dalam Waridin dan Masrukhin, 2006) menyatakan bahwa semakin baik budaya kerja maka kinerja akan semakin tinggi begitu juga sebaliknya. Hal ini berarti bahwa setiap perbaikan budaya kerja kearah yang lebih kondusif akan memberikan sumbangan yang sangat berarti bagi peningkatan kinerja pegawai, demikian juga sebaliknya. Budaya organisai yang kuat akan menghasilkan kepuasan kerja dan kinerja yang tinggi, sebaliknya budaya organisasi yang lemah akan menciptakan kepuasan kerja dan kinerja yang rendah.

Menurut Kreitner dan Kinicki (2003), individu yang mempunyai internal locus of control menunjukkan motivasi yang lebih besar, menyukai hal-hal yang bersifat kompetitif, suka bekerja keras, merasa dikejar waktu dan ingin selalu berusaha lebih baik dari kondisi sebelumnya sehingga mengarah pada pencapaian prestasi yang lebih tinggi. Locus of control memiliki hubungan terhadap kepuasan kerja, yang mana dengan kepuasan kerja yang diperoleh karyawan akan dapat meningkatkan kinerjanya. Individu yang memiliki Locus of Control eksternal kurang keterlibatannya dalam pekerjaan. Mereka lebih terasingkan dalam lingkungan kerja dan tingkat kepuasan kerja mereka terhadap pekerjaan pun lebih rendah, karena mereka yang memiliki Locus of Control eksternal membayangkan diri mereka memiliki kendali yang kecil terhadap hasil organisasi yang penting bagi mereka, sedangkan mereka yang memiliki locus of control internal dalam menghadapi situasi yang sama menghubungkan hasil organisasi dengan tindakan yang mereka lakukan sendiri (Wahyuningsih, 2002).

Rivai (2012) menyatakan bahwa stres kerja merupakan kondisi ketergantungan yang 
menciptakan adanya ketidakseimbangan fisik dan psikis yang mempengaruhi emosi, proses berfikir dan kondisi seorang karyawan. Sehingga dapat dikatakan bahwa stres kerja yang dialami seseorang dapat dilihat baik dari dalam mapun diluar pekerjaan ketika berinteraksi dengan individu lain. Jika interaksi antar individu baik maka akan menghasilkan kinerja yang tinggi dan stres kerja yang rendah begitu juga sebaliknya. Teori ketidak sesuaian menurut Wibowo (2011) adalah mengukur tingkat kepuasan kerja dimana hasil pekerjan diterima individu seperti diharapkan. Stres yang terlalu tinggi menyebabkan kepuasan kerja mulai menurun karena stres mengganggu pelaksanaan pekerjaan yang dapat membuat karyawan tidak mampu mengambil keputusan dan perilaku menjadi tidak teratur, sehingga menurunkan kinerja karyawan (Umar, 2012).

Model Penelitian. Model penelitian yang diajukan dalam penelitian ini adalah sebagai berikut:

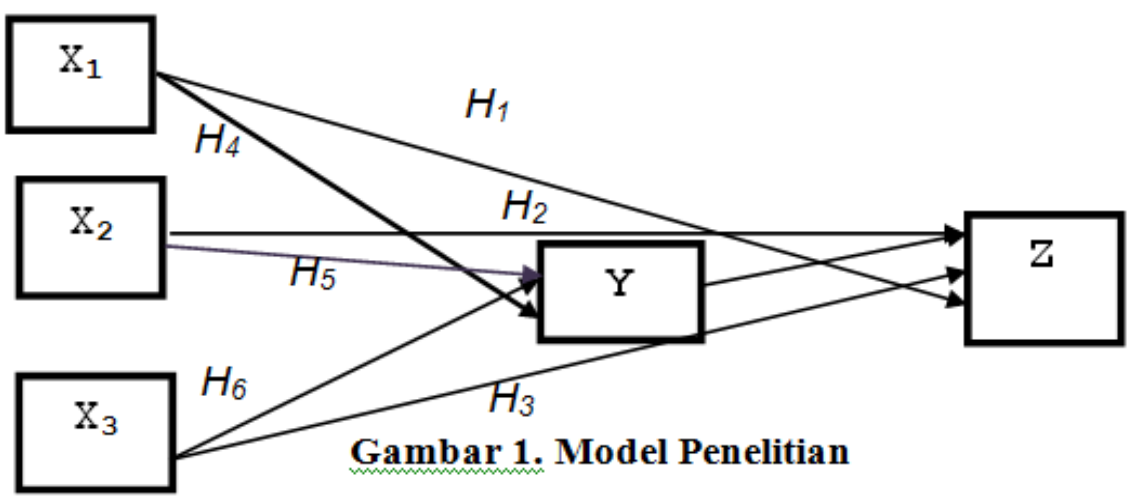

Berdasarkan model diatas maka perumusan hipotesis yang diajukan dalam penelitian ini, diantaranya:

Hipotesis 1 : Budaya organisasi berpengaruh terhadap kinerja aparat pemerintah daerah

Hipotesis 2 : Locus of control berpengaruh terhadap kinerja aparat pemerintah daerah.

Hipotesis 3 : Stres kerja berpengaruh terhadap kinerja aparat pemerintah daerah.

Hipotesis 4 : Kepuasan kerja memediasi pengaruh budaya organisasi dan kinerja pemerintah daerah.

Hipotesis 5 : Kepuasan kerja memediasi pengaruh locus of control dan kinerja pemerintah daerah.

Hipotesis 6 : Kepuasan kerja memediasi pengaruh stres kerja dan kinerja pemerintah daerah.

\section{METODE}

Populasi dan Sampel. Populasi dalam penelitian ini adalah Pegawai Negeri Sipil (PNS) di lingkungan Pemerintah Kabupaten Bengkalis berjumlah 36 SKPD. Adapun metode pengambilan sampel yang digunakan adalah metode purposive sampling, yaitu pemilihan sampel menggunakan kriteria bahwa anggota populasi yang menjadi sampel adalah Pegawai Negeri Sipil daerah Kabupaten Bengkalis yang menjadi Kepala Bidang Satuan Kerja Perangkat Daerah (SKPD), Kepala Sub bagian keuangan, Kepala Sub Bagian Program, Kepala Seksi, Bendahara Pengeluaran dan Bendahara Pengeluaran Pembantu di SKPD. 
Metode Pengumpulan Data. Pengumpulan data dalam penelitian ini dilakukan melalui metode kuesioner, yaitu teknik pengumpulan data yang dilakukan dengan cara memberikan seperangkat pertanyaan atau pernyataan tertulis kepada responden untuk dijawabnya (Sugiyono, 2010).

Skala interval yang digunakan untuk pengukuran data adalah summated rating dari Likert, dimana likert menggunakan lima alternative jawaban dengan kriteria sebagai berikut: 1 = Sangat Tidak Setuju; 2 = Tidak Setuju; $3=$ Netral; $4=$ Setuju; $5=$ Sangat Setuju.

Teknik Analisis Data. Uji Analisis Statistik Deskriptif. Analisis statistik deskriptif yang digunakan untuk memberikan gambaran atau deskripsi mengenai variabel-variabel dalam penelitian ini, yaitu budaya organisasi, locus of control, stres kerja, kepuasan kerja dan kinerja aparat pemerintah daerah.

Uji Validitas Data. Untuk menguji validitas alat ukur, terlebih dahulu dicari nilai korelasi antara bagian-bagian alat ukur secara keseluruhan dengan cara mengkorelasikan tiap butir alat ukur dengan skor total yang merupakan jumlah tiap skor butir (Riduwan dan Kuncoro, 2008, p216). Dasar pengambilan keputusan untuk uji validitas adalah nilai r. Jika nilai rhitung positif dan lebih besar dari $\mathrm{r}_{\text {tabel }}$ maka butir tersebut valid. Sebaliknya, jika $\mathrm{r}_{\text {hitung }}$ tidak positif dan lebih kecil dari rabel maka butir itu tidaklah valid.

Uji Reliabilita Data. Uji reliabilitas ini berguna untuk mendapatkan tingkat ketepatan alat pengumpulan data yang dipakai. Dikatakan reliabel jika data dipakai beberapa kali untuk mengukur objek yang sama akan menghasilkan data yang sama. (Sugiyono, 2008, p172) dan apabila koefisien alpha lebih besar dari 0,6 maka tingkat reliabilitas data dinilai dapat diterima (Sekaran, 2000).

Uji Normalitas Data. Pengujian ini menggunakan uji Kolmogorov-Smirnov. Dimana ada pengambilan keputusan jika Sig $>0,05$ maka data berdistribusi normal. Dan sebaliknya jika Sig $<0,05$ maka pendistribusian data tidak normal.

Metode Analisis Jalur. Metode yang digunakan dalam penelitian ini menggunakan analisis jalur (path analysis). Menurut Riduwan \& Engkos (2012) dalam bukunya yang berjudul Analisis Jalur (Path Analysis), menjelaskan bahwa model path analysis dapat digunakan pengujian kontribusi yang ditunjukkan oleh koefisien jalur pada tiap diagram jalur dari hubungan kausal antar variabel $\mathrm{x}_{1}, \mathrm{x}_{2}, \mathrm{x}_{3}$ terhadap $\mathrm{Y}$ serta dampaknya pada $\mathrm{Z}$ dengan menggunakan metode analisis regresi dari koefisien beta $(\beta)$ melalui program SPSS. (Riduwan dan Kuncoro, 2012).

Selain itu menurut Ghozali (2013) dalam bukunya yang berjudul Aplikasi analisis Multivariate dengan Program IBM SPSS.21 Umlpdate PLS Regresi, menjelaskan bahwa untuk menganalisis jalur dapat menggunakan analisis regresi berganda dengan melihat dari standar koefisien beta $(\beta)$ serta signifikansi setiap variabel. Kemudian untuk melihat mediasi atau hubungan langsung dan tidak langsung dapat dilakukan dengan prosedur yang dikembangkan oleh Sobel (1982). Uji Sobel dilakukan dengan menguji kekuatan pengaruh tidak langsung variabel independen (X) ke variabel dependen (Y) melalui variabel mediasi $(\mathrm{M})$. Pengaruh tidak langsung $\mathrm{X} \rightarrow \mathrm{Y}$ melalui $\mathrm{M}$ dihitung dengan mengalikan jalur $\mathrm{X} \rightarrow \mathrm{M}$ (a); $\mathrm{M} \rightarrow \mathrm{Y}$ (b); atau ab. Jalur koefisien $\mathrm{ab}=\left(\mathrm{c}-\mathrm{c}^{\prime}\right)$ dimana $\mathrm{c}$ adalah pengaruh $\mathrm{X} \rightarrow \mathrm{Y}$ tanpa mengontrol $\mathrm{M}$. sedangkan c' adalah pengaruh $\mathrm{X} \rightarrow \mathrm{Y}$ setelah mengontrol $\mathrm{M}$. Untuk menguji signifikansi pengaruh tidak langsung menggunakan 
nilai t hitung dibandingkan dengan nilai t tabel yaitu $>1,96$. jika nilai t hitung lebih besar dari $\mathrm{t}$ tabel maka dapat disimpulkan terjadi pengaruh mediasi (Ghozali, 2013). Berdasarkan hubungan variabel eksogen dan variabel endogen, maka dapat digambarkan diagram jalur yang menggambarkan paradigma sebagai berikut:

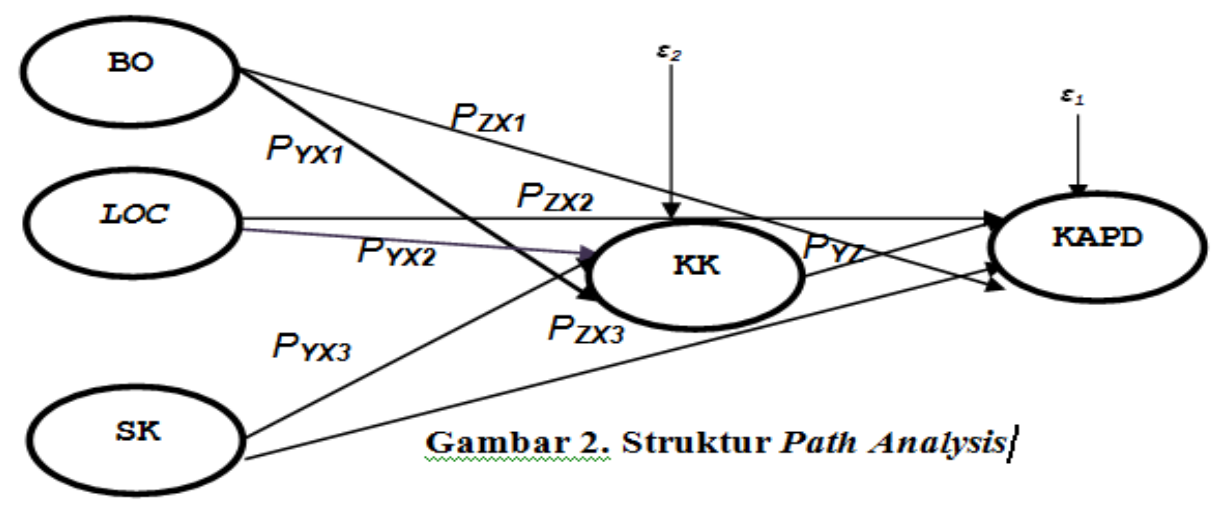

Keterangan:

$\begin{array}{lllll}\mathrm{X}_{1}= & \mathrm{Z} & = & \text { Kinerja Aparat Pemerintah } \\ \mathrm{X}_{2}= & \text { Locus of Control } & \mathrm{r} & = & \text { Daerah } \\ \mathrm{X}_{3}= & \text { Stres Kerja } & \varepsilon & = & \text { Koefisien Korelasi } \\ \mathrm{Y} & = & \text { Kepuasan Kerja } & \varepsilon & \end{array}$

\section{HASIL DAN PEMBAHASAN}

Pengujian terhadap hipotesis penelitian dilakukan dengan analisis jalur (path analysis). Hasil analisis deskriptif terhadap variabel-variabel yang digunakan dalam penelitian ini dapat dilihat pada Tabel.1 berikut:

Tabel 1. Statistik Deskriptif

\begin{tabular}{lccccc}
\hline & N & Minimum & Maximum & Mean & Std. Deviation \\
\hline $\begin{array}{l}\text { Kinerja Aparat } \\
\text { Pemerintah Daerah }\end{array}$ & 183 & 33.00 & 65.00 & 51.3825 & 5.77091 \\
Budaya Organisasi & 183 & 21.00 & 34.00 & 27.8251 & 3.05302 \\
Locus Of Control & 183 & 33.00 & 53.00 & 41.9672 & 4.32968 \\
Stres Kerja & 183 & 22.00 & 51.00 & 35.4590 & 5.19268 \\
Kepuasan Kerja & 183 & 58.00 & 95.00 & 78.1093 & 7.28457 \\
Valid N (listwise) & 183 & & & & \\
\hline
\end{tabular}

Dari Tabel1 dapat dilihat bahwa nilai minimum untuk variabel kinerja aparat pemerintah daerah sebesar 33, nilai maksimum 65 dengan rata-rata 51,38 dan standar deviasi 5,77. Untuk nilai minimum variabel budaya organisasi sebesar 21, nilai maksimum 34 dengan 
rata-rata 27,82 dan standar deviasi 3,05. Untuk nilai minimum variabel locus of control sebesar 33, nilai maksimum 53 dengan rata-rata 41,97 dan standar deviasi 4,33. Untuk nilai minimum variabel stres kerja sebesar 22, nilai maksimum 51 dengan rata-rata 35,46 dan standar deviasi 5,19. Sedangkan untuk nilai minimum variabel kepuasan kerja sebesar 58, nilai maksimum 95 dengan rata-rata 78,11 dan standar deviasi 7,28.

Pada standar deviasi, semakin tinggi tingkat standar deviasi maka akan semakin heterogenitas, yang berarti pernyataan dalam variabel tersebut semakin bervariasi. Sedangkan jika semakin rendah tingkat standar deviasinya maka semakin homogen, artinya bahwa semakin kecil variasi jawaban atas pertanyaan.

Uji Validitas Data. Hasil pengujian validitas data dalam penelitian ini menggunakan korelasi bivariate pearson (korelasi produk momen pearson) yaitu analisis ini dilakukan dengan mengkorelasikan masing-masing skor item dengan skor total. Dimana keseluruhan variabel penelitian terdiri dari 62 pertanyaan yang harus dijawab oleh responden. Dalam penelitian ini untuk mengukur atau menentukan valid atau tidaknya pertanyaan ini apabila korelasi antara masing-masing indikator terhadap total skor konstruk menunjukkan hasil yang signifikan dengan tingkat signifikannya 5\% df $=\mathrm{n}-2(183-2)=181 \mathrm{r}_{\text {tabel }}=0,145$.

Uji Reliabilita Data. Hasil uji reliabilitas data dapat dilihat pada tabel.2 berikut:

Tabel 2. Hasil Uji Reliabilitas Data

\begin{tabular}{lccc}
\hline \multicolumn{1}{c}{ Variabel } & Cronbach's Alpha & Nilai Kritis & Keputusan \\
\hline Kinerja Pemerintah Daerah & 0,832 & 0,6 & Reliabel \\
Budaya Organisasi & 0,745 & 0,6 & Reliabel \\
Locus of control & 0,748 & 0,6 & Reliabel \\
Stres Kerja & 0,815 & 0,6 & Reliabel \\
Kepuasan Kerja & 0,890 & 0,6 & Reliabel \\
\hline
\end{tabular}

Hasil pengujian reliabiltas ini menunjukkan bahwa konstruk-konstruk dari lima variabel diatas diperoleh nilai Cronbach's Alph. Untuk variabel kinerja pemerintah daerah sebesar 0,832 , budaya organisasi 0,745 , locus of control 0,748 , stres kerja 0,815 dan variabel kepuasan kerja 0,890. Sehingga dapat disimpulkan bahwa penelitian ini memiliki nilai reliabilitas $>0,60$ dan dianggap reliabel.

Hasil Normalitas Data. Hasil normalitas data dapat dilihat tada Tabel 3. Berdasarkan hasil uji normalitas pada Tabel 3 diperoleh nilai signifikansi uji kolmogorov smirnov. Dari hasil pengujian diatas nilai signifikansi variabel kinerja pemerintah daerah sebesar 0,076, budaya organisasi 0,96, locus of control 0,157, stres kerja 0,060 dan kepuasan kerja 0,148. Jika dilihat seluruh variabel memiliki nilai signifikansi lebih besar dari 0,05 maka dapat diartikan bahwa data berdistribusi secara normal.

Hasil Analisis Jalur. Penelitian ini menggunakan path analysis dengan membagi hubungan antara variabel dalam 2 sub struktur. Analisis jalur pertama dilakukan pada sub struktur 1 dengan variabel independen, yaitu budaya organisasi, locus of control, stres kerja terhadap kepuasan kerja (variabel intervening). 
Tabel 3. Hasil Uji Normalitas Data

\begin{tabular}{|c|c|c|c|c|c|c|}
\hline & & $\begin{array}{l}\text { Kinerja } \\
\text { Pemerintah } \\
\text { Daerah }\end{array}$ & $\begin{array}{l}\text { Budaya } \\
\text { Organisasi }\end{array}$ & $\begin{array}{c}\text { Locus of } \\
\text { control }\end{array}$ & $\begin{array}{l}\text { Stres } \\
\text { Kerja }\end{array}$ & $\begin{array}{c}\text { Kepuasan } \\
\text { Kerja }\end{array}$ \\
\hline \multicolumn{2}{|l|}{$\mathrm{N}$} & 183 & 183 & 183 & 183 & 183 \\
\hline \multirow{2}{*}{$\begin{array}{l}\text { Normal } \\
\text { Parameters }{ }^{\mathrm{a}, \mathrm{b}}\end{array}$} & Mean & 51.3825 & 27.8251 & 41.9672 & 35.4590 & 78.1093 \\
\hline & Std. Deviation & 5.77091 & 3.05302 & 4.32968 & 5.19268 & 7.28457 \\
\hline \multirow{3}{*}{$\begin{array}{l}\text { Most Extreme } \\
\text { Differences }\end{array}$} & Absolute & .095 & .091 & .083 & 098 & .084 \\
\hline & Positive & .050 & .073 & .083 & .098 & .052 \\
\hline & Negative & -.095 & -.091 & -.057 & -.078 & -.084 \\
\hline \multicolumn{2}{|c|}{ Kolmogorov-Smirnov Z } & 1.279 & 1.233 & 1.127 & 1.324 & 1.140 \\
\hline \multicolumn{2}{|c|}{ Asymp. Sig. (2-tailed) } & .076 & .096 & .157 & .060 & .148 \\
\hline
\end{tabular}

a. Test distribution is Normal.

b. Calculated from data

Tabel 4. Hasil Regresi Berganda Analisis Jalur Sub Struktur 1

\begin{tabular}{|c|c|c|c|c|c|}
\hline \multirow[b]{2}{*}{ Model } & \multicolumn{2}{|c|}{$\begin{array}{l}\text { Unstandardized } \\
\text { Coefficients }\end{array}$} & \multicolumn{3}{|l|}{$\begin{array}{l}\text { Standardized } \\
\text { Coefficients }\end{array}$} \\
\hline & $\mathrm{B}$ & Std. Error & Beta & $\mathrm{t}$ & Sig. \\
\hline 1 (Constant) & 45.488 & 5.124 & & 8.877 & .000 \\
\hline Budaya Organisasi & .841 & .144 & .353 & 5.851 & .000 \\
\hline Locus of control & .591 & .100 & .351 & 5.931 & .000 \\
\hline Stres Kerja & -.439 & .072 & -.313 & -6.124 & .000 \\
\hline
\end{tabular}

a. Dependent Variable: Kepuasan Kerja

Dari gambar diatas dapat dibentuk persamaan struktural 1 sebagai berikut:

$Z=\rho_{\mathrm{yx} 1} X_{1}+\rho_{\mathrm{yx} 2} X_{2}+\rho_{\mathrm{yx} 3} X_{3}$

$\mathrm{KK}=0,841 \mathrm{BO}+0,591 \mathrm{LOC}-0,439 \mathrm{SK}$

Hasil analisis jalur selanjutnya adalah dengan mengamati hubungan variabel independen, yaitu budaya organisasi, locus of control, stres kerja dan kepuasan kerja terhadap kinerja aparat pemerintah daerah (variabel dependen).

Tabel 5. Hasil Regresi linier Berganda Analisis Jalur Sub Struktur 2

\begin{tabular}{|c|c|c|c|c|c|c|}
\hline \multirow{2}{*}{\multicolumn{2}{|c|}{ Model }} & \multicolumn{2}{|c|}{$\begin{array}{l}\text { Unstandardized } \\
\text { Coefficients }\end{array}$} & \multirow{2}{*}{$\begin{array}{c}\text { Standardized } \\
\text { Coefficients }\end{array}$} & \multirow[b]{2}{*}{$\mathrm{t}$} & \multirow[b]{2}{*}{ Sig. } \\
\hline & & $\mathrm{B}$ & Std. Error & & & \\
\hline \multirow[t]{5}{*}{1} & (Constant) & 4.658 & 4.339 & & 1.074 & .284 \\
\hline & Budaya Organisasi & .348 & .111 & .184 & 3.146 & .002 \\
\hline & Locus of control & .267 & .077 & .200 & 3.475 & .001 \\
\hline & Stres Kerja & -.123 & .056 & -.111 & -2.214 & .028 \\
\hline & Kepuasan Kerja & .386 & .053 & .488 & 7.329 & .000 \\
\hline
\end{tabular}

a. Dependent Variable: Kinerja aparat Pemerintah Daerah 
Dari Tabel 5 maka dapat dibuat persamaan struktural 2 sebagai berikut:

$\mathrm{Y}=\rho_{\mathrm{yx} 1} \mathrm{X}_{1}+\rho_{\mathrm{yx} 2} \mathrm{X}_{2}+\rho_{\mathrm{yx} 3} \mathrm{X}_{3}+\rho_{\mathrm{yz}} \mathrm{X}_{3}$

$\mathrm{KPD}=0,348 \mathrm{BO}+0,267 \mathrm{LOC}-0,123 \mathrm{SK}+0,386 \mathrm{KK}$

Hasil Pengujian Hipotesis. Pengaruh budaya organisasi terhadap kinerja aparat pemerintah daerah. Hasil pengujian menunjukan bahwa hipotesis pertama $\left(\mathrm{H}_{1}\right)$ diterima karena nilai uji statistik t hitung yang diperoleh sebesar 3,146 dimana angka tersebut lebih besar jika dibandingkan dengan nilai t tabel sebesar 1,973 dan nilai $\mathrm{P}$ value diperoleh sebesar 0,002 dimana angka tersebut lebih kecil dari tingkat signifikansi yang digunakan sebesar 0,05 .

Berdasarkan hal tersebut diatas dapat disimpulkan bahwa budaya organisasi berpengaruh terhadap kinerja aparat pemerintah daerah, dengan nilai koefisien regresi budaya organisasi sebesar 0,348. Hasil penelitian ini memberi arti bahwa dengan budaya organisasi yang kuat akan memicu pegawai untuk berfikir, berperilaku dan bersikap sesuai dengan nilai-nilai organisasi yang meliputi profesionalisme, percaya pada rekan, keteraturan dan integrasi. Sehingga kesesuaian budaya yang terbentuk dalam diri setiap anggota organisasi dapat mendorong pegawai untuk meningkatkan kinerjanya menjadi lebih baik. Menurut Taurisna dan Ratnawati (2012) bahwa terdapat pengaruh yang searah antara budaya organisasi dan kinerja karyawan, dimana semakin kuat budaya organisasi maka semakin tinggi tingkat kinerja karyawannya karena indikator budaya organisasi yang paling mendominasi adalah perasaan dihargai, sehingga ketika seorang karyawan merasa dihargai dalam sebuah organisasi, maka keberadaan budaya dirasakan oleh karyawan dan diharapkan perilaku mereka sesuai dengan budaya tersebut yang nantinya akan dapat meningkatkan kinerjanya. Hasil penelitian konsisten dengan penelitian yang dilakukan oleh Abdulloh (2006) dan Noer (2007) bahwa budaya organisasi berpengaruh terhadap kinerja, begitu juga penelitian yang dilakukan oleh Oemar (2013), Purba (2009) bahwa budaya organisasi berpengaruh terhadap kinerja. Sementara itu hasil penelitian ini berbeda dengan penelitian yang dilakukan oleh Kurniawan dan Andri (2012).

Pengaruh Locus of Control terhadap kinerja aparat pemerintah daerah. Hasil pengujian menunjukan bahwa hipotesis kedua $\left(\mathrm{H}_{2}\right)$ diterima karena nilai uji statistik $\mathrm{t}$ hitung yang diperoleh sebesar 3,475 dimana angka tersebut lebih besar jika dibandingkan dengan nilai t tabel sebesar 1,973 dan nilai $\mathrm{P}$ value diperoleh sebesar 0,001 dimana angka tersebut lebih kecil dari tingkat signifikansi yang digunakan sebesar 0,05.

Berdasarkan hal tersebut diatas dapat disimpulkan bahwa hipotesis kedua yang diajukan dalam penelitian ini terbukti. Dengan kata lain, terdapat pengaruh antara locus of control terhadap kinerja aparat pemerintah daerah. Hal ini berarti bahwa semakin tinggi internal locus of control ternyata dapat mendorong peningkatan kinerja pegawai pada SKPD di Kabupaten Bengkalis. Keadaan ini dikarenakan pegawai dapat memberdayakan locus of control baik internal maupun eksternal, sehingga terciptanya kondisi kerja yang kompetitif dan berupaya untuk selalu mampu menghadapi masalah dalam menyelesaikan pekerjaannya dengan lebih baik, baik itu secara kualitas, kuantitas, ketepatan waktu dan kemandirian kinerjanya. Hasil penelitian ini sejalan dengan yang dilakukan oleh Kreitner dan Kinicki (2003) dan penelitian yang dilakukan oleh Patten (2005). Sementara itu hasil penelitian ini berbeda dengan penelitian yang dilakukan oleh Hidayat (2012) bahwa locus of control berpengaruh negatif terhadap kinerja auditor, begitu juga dengan penelitian yang dilakukan oleh Artinigsih dan Rasyid (2013). 
Pengaruh Stres Kerja terhadap Kinerja aparat Pemerintah Daerah. Hasil pengujian menunjukan bahwa hipotesis ketiga $\left(\mathrm{H}_{3}\right)$ diterima karena nilai uji statistik t hitung yang diperoleh negatif sebesar -2,214 dimana angka tersebut lebih besar jika dibandingkan dengan nilai $\mathrm{t}$ tabel sebesar $-1,973$ dan nilai $\mathrm{P}$ value diperoleh sebesar 0,028 dimana angka tersebut lebih kecil dari tingkat signifikansi yang digunakan sebesar 0,05.

Berdasarkan hal tersebut diatas dapat disimpulkan bahwa hipotesis ketiga yang diajukan dalam penelitian ini terbukti. Dengan kata lain, terdapat pengaruh antara stres kerja terhadap kinerja aparat pemerintah daerah. Hal ini berarti bahwa Menurut Rehman et al. (2012) stres merupakan situasi dimana akan memaksa seseorang untuk melakukan penyimpangan dari fungsi normal dikarenakan perubahan yang mengganggu atau meningkatkan kondisi fisiologis dan fisikologis, sehingga seseorang tersebut dipaksa untuk menyimpang dari fungsi normal. Apabila stres kerja karyawan meningkat maka akan mempengaruhi kinerja karyawan. Pengaruhnya karyawan tidak dapat bekerja dengan baik (pengaruh negatif), begitu juga sebaliknya. Hasil penelitian ini sejalan dengan yang dilakukan oleh Rozikin (2006) dan penelitian yang dilakukan oleh Merlin dan Prasetyo (2013). Sementara itu hasil penelitian ini berbeda dengan penelitian yang dilakukan oleh Herlin dan Abdulah (2014).

Kepuasan kerja dalam memediasi pengaruh budaya organisasi dan kinerja aparat pemerintah daerah. Hasil pengujian menunjukan bahwa hipotesis keempat $\left(\mathrm{H}_{4}\right)$ diterima karena nilai t sebesar 4,559 lebih besar dari nilai t tabel 1,96 pada tingkat signifikansi 5\%. Hal ini menunjukkan bahwa parameter mediasi tersebut signifikan. Untuk pengambilan kesimpulan apakah mediasi yang terjadi mediasi penuh atau sebagian, diperoleh hasil nilai koefisien regresi indirect effect budaya organisasi terhadap kinerja aparat pemerintah daerah yang turun menjadi 0,6726 dan menjadi tidak signifikan dengan nilai t statistik 3,146 .

Jadi dapat disimpulkan bahwa bentuk mediasi dari model ini adalah mediasi penuh (full mediation), artinya kepuasan kerja merupakan satu-satunya variabel yang memediasi pengaruh budaya organisasi terhadap kinerja pemerintah daerah. Hal ini berarti bahwa apabila persepsi terhadap budaya dalam suatu organisasi baik maka pegawai akan merasa puas terhadap pekerjaannya, begitu sebaliknya. Pegawai yang merasa puas terhadap pekerjaannya dan menganggap pekerjaannya sebagai sesuatu yang menyenangkan akan cenderung memiliki kinerja yang baik. Hal ini konsisten dengan penelitian yang dilakukan oleh Abdulloh (2006) dan Oktaviana (2011), Brahmasari (2008) bahwa budaya organisasi berpengaruh terhadap kinerja melalui kepuasan kerja. Begitu juga penelitian yang dilakukan oleh Lumbanraja (2008) yang menyatakan bahwa apabila nilai-nilai budaya organisasi semakin kuat dianut dan secara konsisten dipakai dalam menyelesaikan masalah dan dalam pencapaian tujuan organisasi oleh seluruh anggota organisasi (seluruh pegawai), maka hal tersebut akan mampu meningkatkan kepuasan kerja pegawai sehingga kinerja pun akan meningkat. Penelitian yang dilakukan Koesmono (2005), menemukan bahwa budaya organisasi berpengaruh positif terhadap motivasi, kepuasan kerja serta kinerja.

Kepuasan kerja dalam memediasi pengaruh locus of control dan kinerja aparat pemerintah daerah. Hasil pengujian menunjukkan bahwa hipotesis kelima $\left(\mathrm{H}_{5}\right)$ diterima karena nilai t sebesar 4,52. Nilai t tersebut lebih besar dari nilai t tabel 1,96 pada tingkat signifikansi 5\%. Hal ini menunjukkan bahwa parameter mediasi tersebut signifikan. Untuk 
pengambilan kesimpulan apakah mediasi yang terjadi mediasi penuh atau sebagian, diperoleh hasil nilai koefisien regresi indirect effect locus of

control terhadap kinerja pemerintah daerah yang turun menjadi 0,4951 dan menjadi tidak signifikan dengan nilai t statistik 3,475.

Jadi dapat disimpulkan bahwa bentuk mediasi dari model ini adalah mediasi penuh (full mediation), artinya kepuasan kerja merupakan satu-satunya variabel yang memediasi pengaruh locus of control terhadap kinerja pemerintah daerah. Hal ini berarti bahwa jika seseorang memiliki locus of control internal, dia yakin akan kemampuan dirinya untuk menyelesaikan suatu permasalahan, maka dengan memiliki locus of control internal akan menimbulkan rasa kepuasan kerja mereka dan juga akan meningkatkan kinerja mereka. Hal ini sejalan dengan penelitian yang dilakukan oleh Jamal dan Baba (2000) dan Patten (2005) bahwa locus of control berpengaruh terhadap kinerja melalui kepuasan kerja.

Kepuasan kerja dalam memediasi pengaruh stres kerja dan kinerja aparat pemerintah daerah. Hasil pengujian menunjukkan bahwa hipotesis keenam $\left(\mathrm{H}_{6}\right)$ diterima karena nilai $t$ sebesar -4,653 lebih besar dari nilai t tabel -1,96 pada tingkat signifikansi 5\%. Hal ini menunjukkan bahwa parameter mediasi tersebut signifikan. Untuk pengambilan kesimpulan apakah mediasi yang terjadi mediasi penuh atau sebagian, diperoleh hasil nilai koefisien regresi indirect effect stres kerja terhadap kinerja pemerintah daerah yang turun menjadi -0,2925 dan menjadi tidak signifikan dengan nilai $\mathrm{t}$ statistik $-2,214$.

Jadi dapat disimpulkan bahwa bentuk mediasi dari model ini adalah mediasi penuh (full mediation), artinya kepuasan kerja merupakan satu-satunya variabel yang memediasi pengaruh stres kerja terhadap kinerja pemerintah daerah. Hal ini berarti bahwa stres kerja yang meningkat akan menjadikan seseorang tidak fokus dalam menjalankan pekerjaannya, sehingga kepuasan kerja mulai menurun karena stres secara otomatis mengganggu pelaksanaan pekerjaan yang dapat membuat pegawai tidak mampu bekerja secara maksimal dan akan menurunkan kinerjanya, begitu juga sebaliknya jadi pengaruhnya negatif. Menurut Mansoor et al. (2011) secara umum stres kerja telah dilihat sebagai pendahulu dari kepuasan kerja, dan sebagai faktor organisasi seperti beban kerja dan kondisi kerja serta berkurangnya kepuasan bisa menjadi sumber stres, sementara kepuasan tinggi dapat meringankan efek stres itu berarti bahwa kedua pekerjaan stres dan kepuasan kerja saling terkait. Hal ini konsisten dengan penelitian yang dilakukan oleh Savira dkk. (2014) bahwa stres kerja berpengaruh terhadap kinerja melalui kepuasan kerja. Sedangkan penelitian yang dilakukan oleh Utami dan Suana (2015) bahwa stres kerja berpengaruh negatif signifikan terhadap kepuasan kerja karyawan.

\section{PENUTUP}

Simpulan. Berdasarkan hasil analisis data, pengujian hipotesis dan pembahasan yang telah dikemukakan pada bab sebelumnya maka dapat disimpulkan beberapa hal sebagai berikut: (1) Terdapat pengaruh budaya organisasi terhadap kinerja aparat pemerintah daerah; (2) Terdapat pengaruh locus of control terhadap kinerja aparat pemerintah daerah; (3) Terdapat pengaruh stres kerja mempunyai pengaruh terhadap kinerja aparat pemerintah daerah Kabupaten BengkaliS; (4) Kepuasan Kerja memediasi pengaruh budaya organisasi dan kinerja aparat pemerintah daerah;(5) Kepuasan Kerja memediasi pengaruh locus of control dan kinerja aparat pemerintah daerah; (6) Kepuasan Kerja memediasi pengaruh 
stres kerja dan kinerja aparat pemerintah daerah.

Saran. Berdasarkan hasil penelitian dan pembahasan yang telah diuraikan sebelumnya maka beberapa hal yang dapat disampaikan oleh peneliti untuk penelitian selanjutnya adalah sebagai berikut: (1) Pemerintah Kabupaten Bengkalis diharapkan untuk lebih meningkatkan kepuasan kerja pegawai, sebaiknya dengan memberikan bimbingan dan dukungan yang lebih besar oleh pimpinan; (2) Pemerintah Kabupaten Bengkalis diharapkan untuk lebih meningkatkan kinerjanya terkait dengan memberi kesempatan kepada pegawai untuk mengambil keputusan sendiri jika dalam keadaan mendesak; (3) Pemerintah Kabupaten Bengkalis diharapkan untuk lebih mengurangi stres kerja, sebaiknya dengan tidak memberi pegawai pekerjaan yang bersifat khusus; (4) Untuk penelitian mendatang sebaiknya dilakukan pada obyek yang berbeda misalnya lokasi yang berbeda karena perbedaan tersebut memungkinkan hasil penelitian yang berbeda.

\section{DAFTAR RUJUKAN}

Abdullah dan Arisanti, Herlin. (2010) "Pengaruh Budaya Organisasi, Komitmen Organisasi dan Akuntabilitas Publik Terhadap Kinerja Organisasi”. Jurnal Ekonomi dan Bisnis. 9 (2): 118-134.

Abdulloh, (2006) 'Pengaruh Budaya Organisasi, Locus of contro, dan Kepuasan kerja terhadap kinerja karyawan pada kantor pelayanan pajak Semarang Barat”. Tesis, Undip: Semarang.

Artiningsih dan Rasyid. (2013) "Pengaruh Locus of Control, Organization Citizenship Behavior dan Kualitas Kehidupan Kerja terhadap Kinerja Karyawan”. Jurnal Aplikasi Manajemen. 11: 365-373.

Astuti, Retno Fajar. (2005) "Pengaruh Kepercayaan pada atasan, Kepuasan kerja dan Komitmen Organisasi terhadap Kinerja Karyawan (Studi Empiris pada Pegawai Pemkab Kendal)”. Tesis. Semarang: Program Pascasarjana Universitas Diponegoro.

Bastian, Indra. (2006) Sistem Perencanaan dan Penganggaran Pemerintah Daerah di Indonesia. Penerbit Salemba Empat: Jakarta

Bimantoro dan Noor. (2012) "Pengaruh Stres Kerja terhadap Kinerja Karyawan di PT. Tonga Tiur Putra”. Jurnal, Universitas Muhammadiyah Jakarta.

Bokti dan Mansor, (2009) "A Prelimanary study on occupational stress and job satisfaction a mong male navy personnel at a naval base in Lumut, Malaysia”. The Journal Of International Social Research, Vol. 2/9, Fall: 2009

Brahmasari, Ida Ayu. Agus Suprayetno (2008) "Pengaruh Motivasi kerja, Kepemimpinan dan Budaya Organisasi terhadap Kepuasan Kerja Karyawan serta Dampaknya pada Kinerja Perusahaan (Studi Kasus pada PT. Pei Hai International Wiratama Indonesia)”. Jurnal Manajemen dan Kewirausahaan, Vol. 10, No. 2, Surabaya.

Brownel, P. (1982) "Participation and Budgeting, Locus of Control and Organizational Effektiviness". The Accounting Review. Vol. VI (4). October: 766-777

Chen \& Silverthorne. (2008) "The impact of locus of control on job stress, job performance and job satisfaction in Taiwan”, Leadership \& Organization Development Journal, 29 (7): 572 - 582

Chi Hsinkuang, (2010) "The Moderating Effect of Locus of Control on Customer Orientation and Job Performance of Sales People”. Journal The Business Review, Cambridge. 16 (2) : 142-146. 
Crider, Andrew. B. (1983) Psychology. Illionis Scot Foresman and Company

Davis, K., \& Newstrom, J. (1996) Perilaku Dalam Organisasi. Jakarta: Erlangga.

Dawis, Rene V., Davis J. Weiss., Llyod H. Lofquist., \& George W. England. (1996) Instrumentation for the Theory of Work Adjustment. Minnesota Studies in Vocational Rehabilitation: xxi.

Fitri, M. A. (2014) Analisis Faktor-faktor yang berhubungan dengan Kejadian Stres Kerja pada Karyawan Bank. Jurnal Kesehatan Masyarakat. Semarang: Universitas Diponegoro. 2 (1).

Fitrie (2011) "Pengaruh Sistem Pengendalian Akuntansi dan Komitmen Organisasi terhadap Kinerja Manajerial”. Skripsi, Fakultas Ekonomi dan Bisnis. Universitas Bengkulu.

Frank H.M. Verbeeten, (2008) Performance management practices in public sector organizations: Impact on performance, Accounting, Auditing \& Accountability Journal, 21 (3): 427 - 454

Frucot, Veronique and Winston T. Shearon. (1997) "Budgetary participation, Locus of Control, and Mexican Managerial Performance and Job Satisfaction”. The Accounting Review, 66 (1): 80 -90.

Foster, Bill, dan Karen R.Seeker, (2001) Pembinaan Untuk Meningkatkan Kinerja Karyawan, Penerjemah : Ramlan, PPM, Jakarta

Ghozali, Imam. (2013) Aplikasi analisis Multivariate dengan Program IBM SPSS.21 . Umlpdate PLS Regresi, Edisi 7, BP Universitas Diponegoro

Handoyo, Seger, (2001) "Model McGrath Sebagai Penjelasan Hubungan Antara Stres Pekerjaan dan Performance”. Jurnal Anima, Surabaya: Fakultas Psikologi Universitas Airlangga. 51: 250-259.

Hidayat, Widi (2012) "ESQ dan Locus of Control sebagai Anteseden Hubungan Kinerja Pegawai dan Penerimaan Perilaku Disfungsional Audit pada Badan Pengawas Daerah (BAWASDA) Jawa Timur”. Jurnal Mitra Ekonomi dan Manajemen Bisnis, Vol. 3, No. 1, April: 2012, 50-74. ISSN 2087-1090

Hofstede, G., Bram Neuijen, Denise Daval Ohayv and Geert Sanders, (1990) Measuring Organizational Cultures: A Qualitative and Quantitateive Study Across Twenty Cases. Administrative Science Quarterly, 35: 286-316.

Jamal, M. and Baba, V.V. (2000) "Job Stress and burnout among Canadian managers and nurses: an empirical examination”. Canadian Journal of Public Health. 91 (6): 4548.

Koesmono, Teman. (2005) "Pengaruh Budaya Organisasi terhadap Motivasi dan Kepuasan Kerja serta Kinerja Karyawan pada Sub Sektor Industri Pengolahan Kayu Skala Menengah di Jawa Timur”. Jurnal Manajemen \& Kewirausahaan, 7 (2): 171181

Keputusan Menteri Pendayagunaan Aparatur Negara Nomor KEP/63/M.PAN/1/2004 tentang Pelayanan Umum.

Kurniati, Merlin dan Prastyo, W.I, (2013) "Pengaruh Stres Lingkungan kerja, dan Budaya organisasi terhadap Kinerja Dosen”. Jurnal Akuntansi Manajemen Bisnis Politeknik Negeri Batam, Batam.

Kurniawan, Rizki dan Andri, (2011) "Pengaruh Komitmen Organisasi, Budaya Organisasi dan Kepuasan Kerja terhadap Kinerja Organisasi Publik (Studi pada Pemerintah Daerah Kabupaten Demak)”. Tesis. Fakultas Ekonomi dan Bisnis. Universitang Diponegoro, Semarang. 
Kreitner, Robert dan Angelo Kinicki, (2003) Perilaku Organisasi. Salemba Empat. Mc. Graw Hill Education. Jakarta.

Kreitner, Robert dan Kinicki, Angelo, (2005) Perilaku Organisasi, buku 1, Edisi kelima, Jakarta : Salemba Empat

Luthans, Fred. (1998) Organizational Behavior. Eight Edition, Mc. Growth-Hill Book coSingapore.

Locke, E., \& Latham, G. (1990) A theory of goal setting \& task performance. Englewood Cliffs. New Jersey: Prentice Hall.

Lefcourt, H . (1986) Locus of Control, Lawrence Erlbaum, New York, NY.

Lumbanraja, Prihatin (2008) "Pengaruh Karakteristik Individu, Gaya Kepemimpinan dan Budaya Organisasi terhadap Kepuasan Kerja dan Komitmen Organisasi (Studi pada Pemerintah Daerah di Provinsi Sumatra Utara)”. Jurnal Aplikasi Manajemen. 7 (2), Mei 2009. ISSN: 1693-5241.

Mahoney, T. A., T. H. Jerdee and S. J. Carroll. (1963) Development of Managerial Performance: A Research Approach, Cincinnati: South Western Publ. Co.

Mansoor Muhammad., Sabtain Fida., Saima Nasir, Zubair Ahmad, (2011) "The Impact of Job Stress on Employee Job Satisfaction A Study on Telecommunication Sector of Pakistan”, Journal of Business Studies Quarterly, 2 (3): 50-56

Menezes, Alvaro, (2008) "Analisis Dampak Locus of control terhadap Kinerja dan Kepuasan Kerja Internal Auditor”. Tesis, Undip: Semarang.

Noer Mohammad, Rihardjo Ikhsan Budi, (2007) "Pengaruh Budaya Organisasi, Locus of Control dan Kebijakan Sektor Publik terhadap Kinerja Aparat Pelayanan Publik UPT Dipenda Bangkalan”. Jurnal Akuntansi, Manajemen Bisnis dan Sektor Publik (JAMBSP), ISSN 1829-9857: Surabaya.

Nurkhamid, Muh. (2008) "Implementasi Inovasi Sistem Pengukuran Kinerja Instansi Pemerintah”, Jurnal Akuntansi Pemerintah, 3 (l): 45-76.

Oemar, Yohanas (2013) "Pengaruh Budaya Organisasi, Kemampuan Kerja dan Komitmen Organisasi terhadap Organizational Citizen Behavior (OCB) Pegawai pada BAPPEDA Kota Pekanbaru”. Jurnal Aplikasi Manajemen, 11 (1), Maret 2013. ISSN: 1693-5241.

Oktaviana, Nur. (2011) Pengaruh Budaya Organisasi terhadap Motivasi dan Kepuasan Kerja serta Kinerja Karyawan (Pada PT. Mirota Kampus di Yogyakarta). Tesis. Yogyakarta:UPN

Patten, M. D. (2005) “An Analysis of The Impact of Locus of Control on Internal Auditor Job Performance and Satisfaction”. Managerial Auditing Journal, Vol. 20 No: 9, 1016-1029.

Peraturan Menteri Pendayagunaan Aparatur Negara dan Reformasi Birokrasi Republik Indonesia, Nomor 38 tahun 2012 tentang Pedoman Penilaian Kinerja Unit Pelayanan Publik.

Peraturan Pemerintah Republik Indonesia, Nomor 8 Tahun 2006 tentang Pelaporan Keuangan dan Kinerja Instansi Pemerintah.

Price, J. (2001) "Reflections on The Determinants of Voluntary Turnover". International Journal of Manpower , 22 (7): 600-624.

Purba, Sukarman (2009) "Pengaruh Budaya Organisasi, Modal Intelektual dan Perilaku Inovatif terhadap Kinerja Pemimpin Jurusan di Universitas Negeri Medan”. Jurnal Bisnis dan Ekonomi. 13 (2): 150-167.

Rehman, Muttie ur., Rabbia Irum, Namra Tahir, Zara Ijaz, Uzma Noor, Ume Salma. 
(2012) "The Impact Job Stress on Employee Job Satisfaction: A Study on Private Collages of Pakistan”. Journal of Business Studies Quarterly. 3 (3): 50-56.

Riduwan dan Engkos, Achmad Kuncoro. (2012) Analisis Jalur. Bandung: Alfabeta.

Rivai, V., \& Mulyadi, D. (2012) Kepemimpinan dan Perilaku Organisasi. Jakarta: Rajawali Pers.

Rivai, Veithzal. (2004) Manajemen Sumber Daya Manusia untuk Perusahaan. Raja Grafindo Persada, Jakarta.

Robbins, Stepen. (2007) Perilaku Organisasi: Terjemahan: Benyamin Molan. New Jersey Prentice Hall, Inc.

Robbins dan Judge. (2008) Perilaku Organisasi, Edisi Duabelas, Penerbit Salemba Empat: Jakarta.

Rotter, J. (1986) Generalized expectancies for internal versus external control of reinforcement. Psychological iWonographs, 80: 1-28.

Rozikin, Zainur. (2006) "Pengaruh Konflik Peran dan Stres Kerja terhadap Kinerja Karyawan pada Bank Pemerintah di Kota Malang”. Jurnal Aplikasi Manajemen. 4 (2).

Utami, Sagung Diah Putri \& Suana, Wayan (2015) "Pengaruh Kepemimpinan Transaksional dan Stres Kerja terhadap Kepuasan Kerja Karyawan”. Jurnal Manajemen Unud, 4 (4):960-975: ISSN: 2302-8912

Savira, Halida dan Noermijati. (2014) "Pengaruh stres kerja dan locus of control terhadap kepuasan kerja dan kinerja pegawai Bagian Layanan PT. Bank Negara Indonesia (Persero) Tbk. Cabang Malang”. Jurnal Aplikasi Manajemen. 12 (1), Universitas Brawijaya, Maret: 2014.

Sedarmayanti. (2009) Sumber Daya Manusia dan Produktivitas Kerja. Bandung: CV Mandar Maju.

Sekaran, U. (2006) Reseach Methods For Business, $4^{\text {th }}$ Edition. Salemba Empat. Jakarta.

Sihaloho, F. Laurensius dan Halim, A. (2005) "Pengaruh Faktor-Faktor Rasional, Politik dan Kultur Organisasi Terhadap Pemanfaatan Informasi Kinerja Instansi Pemerintah Daerah”. Simposium Nasional Akuntansi VIII Solo, 15- 16 September. Hal. 774-790

Sugiyono (2010) Metode penelitian Bisnis. CV Alfabeta. Bandung.

Spector, Paul E. (1982) "Measurement of Human Service Staff Satisfaction: Development of Job Satisfaction Survey”. American Journal of Community of Psychology.

Taufik Taufeni, (2013) "Peran Monitoring dan Evaluasi terhadap Sistem Akuntabilitas Kinerja Instansi Pemerintah Daerah”. Jurnal Akuntansi, 1 (2): 199-212, ISSN: 23374314.

Taurisna, Chaterina Melina dan Ratnawati, Intan (2012) “Analisis pengaruh Budaya Organisasi dan Kepuasan Kerja terhadap Komitmen Organisasional dalam Meningkatkan Kinerja Karyawan”. Jurnal Bisnis dan Ekonomi (JBE), 19 (2): 170187. ISSN: 1412-3126.

Umar, Husein. (2012) Riset Sumber Daya Manusia Dalam Organisasi. PT. Gramedia Pustaka Utama, Jakarta

Wahyuningsih, T., (2002) “Dampak Pergantian Pimpinan pada Kinerja Organisasi”. Jurnal Administrasi dan Bisnis. 1 (2): 29-42

Waridin dan Masrukhin, (2006) "Pengaruh Motivasi Kerja, Kepuasan Kerja, Budaya Organisasi, dan Kepemimpinan Terhadap Kinerja Pegawai”. Ekobis, 7 (2).

Wibowo. (2010). Manajemen Kinerja. Jakarta: PT. Raja Grafindo Persada. 